\title{
Children with Kawasaki disease or Kawasaki-like syndrome (MIS-C/PIMS) at the time of COVID-19: are they all the same? Case series and literature review
}

\author{
A. Marino1, T. Varisco', G. Quattrocchi², A. Amoroso², D. Beltrami', S. Venturiello1, \\ A. Ripamonti' ${ }^{1}$ A. Villa ${ }^{1}$, M. Andreotti ${ }^{1}$, M. Ciuffreda ${ }^{3}$, R. Cimaz ${ }^{4,5}$ \\ ${ }^{1}$ Department of Pediatrics, Desio Hospital, ASST Monza, (MB), Italy; ${ }^{2}$ Department of Pediatrics, Papa \\ Giovanni XXIII Hospital, University of Milano-Bicocca, Bergamo, Italy; ${ }^{3}$ Department of Cardiology, Papa \\ Giovanni XXIII Hospital, Bergamo, Italy; ${ }^{4}$ ASST G. Pini-CTO, Milan, Italy; ${ }^{5}$ Department of Clinical Sciences and \\ Community Health, and Research Center for Adult and Pediatric Rheumatic Diseases, University of Milan, Italy
}

\section{SUMMARY}

Since the coronavirus disease 2019 (COVID-19) outbreak started, children have been considered marginally involved compared to adults, with a quite significant percentage of asymptomatic carriers. Very recently, an overwhelming inflammatory activation, which shares clinical similarities with Kawasaki disease (KD), has been described in children exposed to COVID-19.

We report three KD-like cases that occurred during the pandemic of severe acute respiratory syndrome coronavirus 2 (SARS-CoV-2) in a highly affected area of Northern Italy. The clinical presentation was characterized by the presence of unremitting fever, diarrhea and elevated inflammatory markers. Case \#1 and Case \#2 occurred one week apart and shared other clinical features: laboratory tests confirmed COVID-19 exposure and high inflammatory activation with myocardial involvement. Case \#3 followed a more typical pattern for KD. Interestingly, this patient showed lower levels of procalcitonin, C-reactive protein, D-dimers, and ferritin compared to the other two cases, whereas platelet count was higher.

We hypothesize that SARS-CoV-2 might act in children as a trigger, either inducing a classical KD phenotype or causing a systemic inflammatory response leading to a severe KD-like phenotype, eventually characterized by myocardial impairment.

We think that bringing these cases and their differences to the attention of the rheumatology community during the COVID-19 pandemic will be beneficial in order to highlight the importance of early diagnosis and to increase awareness of this new phenomenon.

Key words: Kawasaki disease, COVID-19, SARS-CoV-2, myocarditis, PIMS-TS; Macrophage Activation Syndrome (MAS).

Reumatismo, 2021; 73 (1): 48-53

\section{INTRODUCTION}

T he first evidence about the spreading of severe acute respiratory syndrome coronavirus 2 (SARS-CoV-2) in Italy dates back to late February 2020, and Lombardy was the most affected area in the country. Since the coronavirus disease 2019 (COVID-19) outbreak started, children have been considered marginally involved compared to adults, with a quite significant percentage of asymptomatic carriers. Although COVID-19 affects mainly the lungs, causing an interstitial disease, the increasing knowledge about this disease has led to understand other possible ways in which SARS-CoV-2 may cause damage in humans. Very recently, an overwhelming inflammatory activation, which shares some clinical similarities with Kawasaki disease (KD), has been described in children exposed to SARS-CoV-2 (1-7). Herein we report three consecutive cases of patients diagnosed with KD in a hospital in Lombardy, Italy, during the SARS-CoV-2 outbreak. We also review similar published cases. 


\section{MATERIALS AND METHODS}

We collected retrospectively 3 consecutive cases of children diagnosed with $\mathrm{KD}$ at Desio Hospital, Monza, Italy over a 10week period (March to mid-May 2020) from the beginning of the outbreak in Italy. Inclusion criteria: A diagnosis of $\mathrm{KD}$ according to the American Heart Association (2). Exclusion criteria: The identification of a potentially alternative cause (associated with either infection or cancer). The patients were screened for COVID-19 by reverse-transcription-polymerase-chainreaction test (RT-PCR) on nasopharyngeal swabs and serology tests. Patient data were derived from medical records. A review of the relevant literature published in English on PubMed was conducted. "COVID19", "SARS-CoV-2", "Kawasaki disease", "paediatric inflammatory multisystem syndrome temporally associated with SARS-CoV-2 (PIMS-TS)", "multisystem inflammatory syndrome in children (MIS-C)" were used as keywords. The literature review was conducted between May and August 2020. We included only studies with at least 8 patients and no more than 3 reports from the same area, so as to capture the worldwide distribution of this phenomenon. Finally, AM and RC selected the eligible studies.

\section{CASE REPORTS}

\section{Case \#1}

A previously healthy 5-year-old Caucasian boy was admitted with a history of 5 days of fever, diarrhea, and rash. Clinical examination revealed poor general conditions, edema of hands and feet, and a blotchy rash over the trunk. Laboratory tests are shown in Table I. Chest X-ray showed a faint opacity on the right lung base. Empiric antibiotic therapy was started along with appropriate electrolyte correction. COVID-19 infection was suspected, but the RT-PCR of two nasopharyngeal swabs $24 \mathrm{~h}$ apart was negative. The patient developed limbic sparing conjunctivitis and cracked lips. The day after the admission, blood tests revealed lymphocytopenia, mild anemia and thrombocytopenia $\left(2.9 \times 10^{3} / \mu \mathrm{L}, 9.3 \mathrm{~g} / \mathrm{dL}\right.$, $102 \times 10^{3} / \mu \mathrm{L}$ ) along with mild elevation of ferritin $(375 \mathrm{ng} / \mathrm{mL})$. Transthoracic echocardiography (TTE) revealed left ventricu-

Table I - Laboratory results at disease presentation.

\begin{tabular}{|l|c|c|c|c|}
\hline & Reference & \multicolumn{3}{|c|}{ Results at disease presentation } \\
\cline { 3 - 5 } & range & Case \#1 & Case \#2 & Case \#3 \\
\cline { 3 - 5 } & $4.5-13$ & 4.4 & 11.7 & 11.3 \\
\hline White blood cell count, $\times 10^{3} / \mathrm{hL}$ & $25-65$ & 83 & 82 & 65 \\
\hline Neutrophil (\%) & $11.5-14.8$ & 11.8 & 12.1 & 11.0 \\
\hline Hemoglobin, $\mathrm{g} / \mathrm{dL}$ & $140-450$ & 136 & 223 & 403 \\
\hline Platelet $\times 10^{3} / \mathrm{LL}$ & $<0.5$ & 9.6 & 18 & 6.4 \\
\hline C-reactive protein, $\mathrm{mg} / \mathrm{dL}$ & $1-13$ & 54 & 55 & - \\
\hline Erythrocyte sedimentation rate, $\mathrm{mm} / \mathrm{h}$ & $<0.5$ & 10.42 & 2.11 & 0.96 \\
\hline Procalcitonin, $\mathrm{ng} / \mathrm{ml}$ & $150-500$ & 4028 & 2168 & 1053 \\
\hline D-dimers, $\mathrm{mcg} / \mathrm{L}$ & $10-142$ & 375 & 362 & 259 \\
\hline Ferritin, $\mathrm{ng} / \mathrm{ml}$ & $\mathrm{AST}<77$ & $30 / 20$ & $25 / 26$ & $52 / 101$ \\
\hline AST/ALT, U/L & ALT $<48$ & & & 138 \\
\hline Sodium, $\mathrm{mEq} / \mathrm{L}$ & $135-145$ & 122 & 136 & 13 \\
\hline Troponin I, $\mathrm{ng} / \mathrm{L}$ & $<53$ & 35 & 925 & 1019 \\
\hline NT-proBNP, $\mathrm{ng} / \mathrm{L}$ & $0-100$ & 927 & 3391 & Yes \\
\hline Pyuria & Yes/No & No & No & \\
\hline
\end{tabular}

NT-proBNP, N-terminal pro-brain natriuretic peptide. 
lar (LV) hypokinesis at the inferolateral area, and lower portion of the septum with an estimated LV ejection fraction (LVEF) of $45 \%$; dilatation of right ventricle (RV) and inferior vena cava (IVC). Increased levels of $\mathrm{N}$-terminal pro-brain natriuretic peptide (NT-proBNP) were found, whereas troponin I was normal. The patient was therefore diagnosed with KD with myocardial involvement and intravenous immunoglobulins (IVIG) $(2 \mathrm{~g} / \mathrm{kg}$ over $48 \mathrm{~h})$ were started ( $6^{\text {th }}$ day of fever) along with methylprednisolone $(2 \mathrm{mg} / \mathrm{kg} /$ day $)$ and aspirin (ASA) at anti-inflammatory dosage. A concomitant diuretic therapy (furosemide and spironolactone) and low-molecular weight heparin were initiated due to cava system congestion and high D-dimers levels. The fever subsided and inflammatory parameters decreased with rapid normalization of previously described TTE findings; the medical therapy was then modified accordingly. The patient was found to be positive for SARS-CoV-2 immunoglobulin G (IgG) and his mother tested positive for COVID-19 on nasopharyngeal swab (RT-PCR).

\section{Case \#2}

An 11-year-old Caucasian boy presented with 2 days of fever and diarrhea. He complained also of diffuse myalgia and abdominal pain. Six weeks earlier, his parents had symptoms consistent with COVID-19 infection and all the family was quarantined. He had experienced one day of fever two weeks before hospitalization. On admission, the physical exam was unremarkable. Laboratory tests are shown in Table I. Chest X-ray showed right lung thickening. He tested negative for COVID-19 on two nasopharyngeal swabs $24 \mathrm{~h}$ apart. Antibiotic treatment was given, but fever persisted. The patient underwent cardiac investigations due to tachycardia and the clinical similarities with the previous case. TTE detected LV hypokinesis of the inferolateral area with a LVEF of $45 \%$ and tubular dilatation of left main coronary artery (LMCA) along with echo-brightness $(2.2 \mathrm{z}$ score). Elevated NT-proBNP and troponin I were found. A diagnosis of atypical KD was made and immunomodulatory thera- py was started ( $5^{\text {th }}$ day of fever) with the same protocol of Case \#1 along with diuretics. Fever subsided along with cardiac abnormalities and laboratory features of inflammation. The patient was found to be positive for SARS-CoV-2 serology, and his mother also tested positive for COVID-19.

\section{Case \#3}

A 5-month-old Caucasian girl was admitted with a history of 2 days of fever and rash along with diarrhea. Besides irritability and a confluent erythematous rash at the trunk, her clinical examination was unremarkable. Laboratory tests are shown in Table I. She had mild elevation of liver enzymes and sterile pyuria. Abdominal ultrasound revealed gallbladder hydrops. Chest X-ray showed a dim opacity on the left lung base. Extensive infection panel was negative. She screened negative for SARS-CoV-2 infection (two nasopharyngeal swabs 24 $\mathrm{h}$ apart and serology) as her mother. Despite the wide spectrum antibiotic therapy, fever persisted. TTE pointed out dilatation of both right coronary artery (RCA) and LMCA (z score 2.5 and 2.8, respectively). Troponin I was normal, whereas increased levels of NT-proBNP were found. The patient was therefore diagnosed with incomplete $\mathrm{KD}$ with coronary artery involvement and intravenous immunoglobulins (IVIG) $(2 \mathrm{~g} / \mathrm{kg}$ over $48 \mathrm{~h})$ were started $\left(6^{\text {th }}\right.$ day of fever) along with methylprednisolone (2 $\mathrm{mg} / \mathrm{kg} /$ day) and ASA at anti-inflammatory dosage. The day after IVIG administration, fever subsided with progressive normalization of inflammatory markers and coronary artery size reduction.

\section{Literature review}

During this pandemic, several clusters of children with a hyperinflammatory status and clinical features similar to those seen in KD have been described. So far, reported cases ranged from classic KD with or without positive COVID-19 screening, to more complicated cases in which the overwhelming inflammation led to severe cardiac involvement and/or shock requiring intensive care. In Table II the main published articles are summarized (2-4, 8-14). 
Table II - Studies describing KD-like patients during COVID-19 outbreak.

\begin{tabular}{|c|c|c|c|c|c|c|c|c|c|c|c|c|}
\hline & 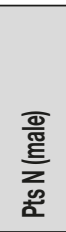 & 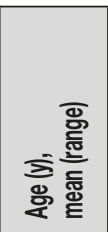 & 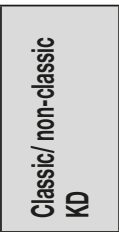 & 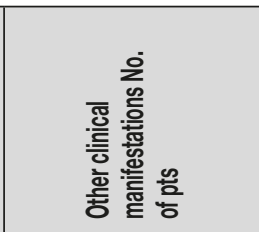 & 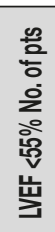 & 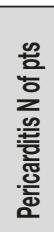 & $\frac{2}{2}$ & 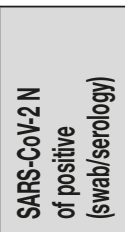 & 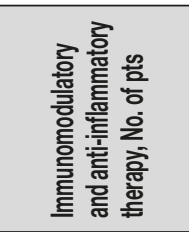 & 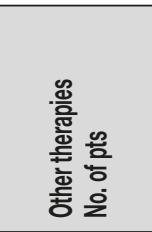 & 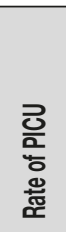 & 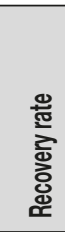 \\
\hline $\begin{array}{l}\text { Verdoni L, } \\
\text { et al. (2) }\end{array}$ & $\begin{array}{l}10 \\
(7)\end{array}$ & $\begin{array}{c}7.5 \\
(2.9-16)\end{array}$ & $5 / 5$ & $\begin{array}{l}6 \text { Diarrhea, } 4 \text { meningism, } \\
5 \text { hypotension, } 5 \text { MAS }\end{array}$ & 5 & 4 & 1 & $8(2 / 8)$ & $\begin{array}{l}10 \mathrm{IVIG} \\
8 \mathrm{CCS} \\
2 \mathrm{ASA}\end{array}$ & 2 Inotropes & - & $100 \%$ \\
\hline $\begin{array}{l}\text { Riphagen S, } \\
\text { et al. (3) }\end{array}$ & $\begin{array}{l}8 \\
(5)\end{array}$ & $\begin{array}{c}8.9 \\
(4-14)\end{array}$ & NA & $\begin{array}{c}7 \text { Gl symptoms, } \\
2 \text { odynophagia, } 5 \text { ascites, } \\
3 \text { pleural effusion } \\
8 \text { vasoplegic shock }\end{array}$ & 5 & - & 1 & $2\left(2 / \mathrm{NA}^{\mathrm{a}}\right)$ & $\begin{array}{l}8 \mathrm{IVIG} \\
5 \mathrm{CCS} \\
3 \mathrm{ASA} \\
1 \mathrm{IFX}\end{array}$ & $\begin{array}{l}\text { All received } \\
\text { inotropes, } \\
1 \text { heparin, }\end{array}$ & $100 \%$ & $87 \%^{b}$ \\
\hline $\begin{array}{l}\text { Belhadjer Z } \\
\text { et al. ( } 8)\end{array}$ & $\begin{array}{c}35 \\
\text { (18) }\end{array}$ & $\begin{array}{c}10 \\
(\text { median }) \\
(2-16)\end{array}$ & NA & $\begin{array}{c}35 \text { asthenia, } 11 \mathrm{Gl} \\
\text { symptoms, } 15 \text { rhinorrhea, } \\
11 \text { meningism, } 6 \text { chest } \\
\text { pain, } 28 \text { cardiogenic shock } \\
\text { with collapse }\end{array}$ & 35 & 3 & 6 & $31(12 / 30)$ & $\begin{array}{l}25 \text { IVIG } \\
12 \text { CCS } \\
3 \text { ANA }\end{array}$ & $\begin{array}{l}28 \text { inotropes, } \\
23 \text { heparin }\end{array}$ & $100 \%$ & $71 \%^{\circ}$ \\
\hline $\begin{array}{l}\text { Toubiana J, } \\
\text { et al. ( }(9)\end{array}$ & $\begin{array}{l}21 \\
(9)\end{array}$ & $\begin{array}{c}7.9 \\
\text { (median) } \\
(3.7-16.6)\end{array}$ & $11 / 10$ & $\begin{array}{c}21 \mathrm{Gl} \text { symptoms, } \\
2 \text { arthralgia, } 12 \text { irritability, } \\
4 \text { peritoneal effusion, } \\
6 \text { meningism, }\end{array}$ & 16 & 10 & 8 & $19(8 / 19)$ & $\begin{array}{l}21 \mid \mathrm{IVIG} \mathrm{G}^{\mathrm{d}} \\
7 \mathrm{CCS} \\
3 \mathrm{ASA} \\
1 \mathrm{IFX}\end{array}$ & $\begin{array}{c}11 \text { fluid boluses, } \\
8 \text { vasoactive } \\
\text { agents, } \\
14 \text { inotropes }\end{array}$ & $81 \%$ & $100 \%$ \\
\hline $\begin{array}{l}\text { Pouletty M, } \\
\text { et al. (10) }\end{array}$ & $\begin{array}{l}16 \\
(8)\end{array}$ & $\begin{array}{c}10 \\
\text { (median) } \\
\text { IQR } \\
(4.7-12.5)\end{array}$ & $10 / 6$ & $\begin{array}{c}13 \mathrm{Gl} \text { symptoms, } \\
11 \text { haemodynamic failure, } \\
2 \text { orchitis, irritability, } \\
2 \text { cough, } 2 \text { Raynaud } \\
\text { syndrome, } 3 \text { meningism, } \\
9 \text { acute renal failure }\end{array}$ & 7 & 4 & 3 & $11(9 / 7)$ & $\begin{array}{l}15 \mathrm{IVIG} \\
3 \mathrm{CCS} \\
7 \mathrm{ASA} \\
1 \mathrm{ANA} \\
1 \mathrm{TOCl} \\
1 \mathrm{HQL}\end{array}$ & $\begin{array}{l}7 \text { fluid boluses, } \\
6 \text { inotropes }\end{array}$ & $43 \%$ & $87 \%{ }^{\dagger}$ \\
\hline $\begin{array}{l}\text { Whittaker E, } \\
\text { et al. (11) }\end{array}$ & $\begin{array}{l}58 \\
(38)\end{array}$ & $\begin{array}{c}9 \text { (median) } \\
\text { IQR } \\
(5.7-14)\end{array}$ & $13 / 0$ & $\begin{array}{c}31 \text { Gl symptoms, } \\
6 \text { sore throat, } \\
15 \text { headeache, } 13 \text { acute } \\
\text { renal failure, } 4 \text { arrhythmia }\end{array}$ & 29 & - & 8 & $45(15 / 40)$ & $\begin{array}{l}41 \text { IVIG } \\
37 \text { CCS } \\
\text { 3ANA } \\
8 \text { IFX }\end{array}$ & $\begin{array}{l}29 \text { fluid boluses } \\
\text { and inotropes }\end{array}$ & $50 \%$ & $98 \% 9$ \\
\hline $\begin{array}{l}\text { Feldstein LR, } \\
\text { et al. (12) }\end{array}$ & $\begin{array}{c}186 \\
(115)\end{array}$ & $\begin{array}{c}8.3 \\
\text { (median) } \\
\text { IQR } \\
(4.8-14.2)\end{array}$ & $38 / 36$ & $\begin{array}{c}171 \mathrm{Gl} \text { symptoms, } \\
17 \text { acute renal failure, } \\
28 \text { myalgia or myositis, } \\
6 \text { joint involvement, } 92 \text { pleural } \\
\text { effusion, } 12 \text { arrhythmia }\end{array}$ & 38 & 26 & 15 & $131(73 / 58)$ & $\begin{array}{c}144 \text { IVIG } \\
91 \text { CCS } \\
24 \text { ANA } \\
14 \text { anti IL-6 } \\
\text { (TOCl or siltuximab) }\end{array}$ & $\begin{array}{l}90 \text { vasoactive } \\
\text { agents, } \\
87 \\
\text { anticoagulants }\end{array}$ & $80 \%$ & $70 \%$ \\
\hline $\begin{array}{l}\text { Dufort E, } \\
\text { et al. (13) }\end{array}$ & $\begin{array}{l}99 \\
(53)\end{array}$ & $(-)^{\prime}$ & $\begin{array}{c}36 \\
\text { (typical or } \\
\text { incomplete) }\end{array}$ & $\begin{array}{l}79 \text { Gl symptoms, } 11 \text { chest } \\
\text { pain, } 28 \text { headache, } \\
17 \text { myalgia, } 4 \text { arthralgia, } \\
16 \text { sore throat, } 31 \text { cough }\end{array}$ & 52 & - & 9 & $95(50 / 76)$ & $\begin{array}{c}69 \mathrm{IVIG} \\
63 \mathrm{CCS} \\
3 \mathrm{ASA}\end{array}$ & $\begin{array}{l}61 \text { vasoactive } \\
\text { agents }\end{array}$ & $80 \%$ & $98 \% m$ \\
\hline $\begin{array}{l}\text { Ramcharan T, } \\
\text { et al. (14) }\end{array}$ & $\begin{array}{c}15 \\
(11)\end{array}$ & $\begin{array}{c}8.8 \\
\text { (median) } \\
\text { IQR } \\
(6.4-11.2)\end{array}$ & $0 / 8$ & $\begin{array}{l}13 \mathrm{Gl} \text { symptoms, } \\
4 \text { myalgia, } 4 \text { lethargy, } \\
7 \text { pleural effusions }\end{array}$ & 12 & 8 & 14 & $-(2 / 12)$ & $\begin{array}{l}10 \mathrm{IVIG}^{\mathrm{n}} \\
5 \mathrm{CCS}\end{array}$ & $\begin{array}{l}10 \text { inotropes } \\
\text { or vasoactive } \\
\text { agents } 10 \text { fluid } \\
\text { boluses }\end{array}$ & $67 \%$ & $100 \%$ \\
\hline $\begin{array}{l}\text { Mamishi S, } \\
\text { et al. (4) }\end{array}$ & $\begin{array}{l}45 \\
(24)\end{array}$ & $\begin{array}{c}7 \text { (median) } \\
(0.8-17)\end{array}$ & $\begin{array}{l}\text { NA (31 with } \\
\text { KD-like } \\
\text { disease }\end{array}$ & $\begin{array}{l}23 \text { Gl symptoms, } \\
17 \text { myalgia, } 8 \text { pleural } \\
\text { effusions, } 16 \text { cough, } \\
13 \text { acute renal failure }\end{array}$ & 8 & 1 & 14 & $-(10 / 35)$ & $\begin{array}{l}18 \mathrm{IVIG} \\
27 \mathrm{CCS}\end{array}$ & NA & NA & $89 \%{ }^{\circ}$ \\
\hline
\end{tabular}

Pts: patients; Y: years; IQR: interquartile range; KD: Kawasaki disease; LVEF: left ventricular ejection fraction; CAA: coronary artery abnormalities; NA: not applicable; Gl: gastrointestinal; IVIG: intravenous immunoglobulins; ASA: aspirin; CCS: corticosteroids; IFX: infliximab; ANA: anakinra, TOCI: tocilizumab; HLQ: hydroxychloroquine. a) 2 patients tested positive after an initial negativity, other 3 patients had a verified familial exposure, no serology test was performed; b) 1 pt demise due to cerebral artery infarction; c) 7 pts still in hospital or with residual LV dysfunction; d) 5 pts received a II IVIG infusion, 4 of them in combination with CCS; e) 4 pts received a II IVIG infusion, 1 received a second IVIG infusion with CSS, 2 received CSS and finally, 1 received ANA and 1 TOCl; $f$ ) 2 pts had a residual mild cardiac dysfunction; g) 1 death; h) 39 pts received II IVIG; i) 4 deaths, 52 still hospitalized; I) A total of 31 patients (31\%) were 0 to 5 years of age, 42 (42\%) were 6 to 12 years of age, and 26 (26\%) were 13 to 20 years of age; $m$ ) 2 deaths, both pts neither received IVIG, systemic glucocorticoids, or immunomodulators; n) 2 pts received a II IVIG infusion; o) 5 patients died, 4 of which with underlying diseases. 
Interestingly, Whittaker et al. found several differences between PIMS-TS and KD, thus supporting the hypothesis of a condition different from KD (11). Indeed, PIMS-TS patients were older, had higher levels of white blood cell count, neutrophil count, and CRP than KD patients. Furthermore, in this group of patients, lower levels of lymphocytes, hemoglobin, and platelets were identified as well as increased troponin levels compared to KD (11). In the larger cohort published by Feldstein and colleagues (186 patients), the majority had a verified SARS-CoV-2 exposure $(88 \%)$ and needed intensive care (80\%) (12). Moreover, only $40 \%$ of the cohort presented with KD-like features, highlighting the differences with KD (12).

\section{DISCUSSION AND CONCLUSIONS}

We reported three KD-like cases that occurred during the SARS-CoV-2 pandemic in a highly affected area of Northern Italy. Case \#1 and Case \#2 occurred one week apart and shared some clinical features: laboratory tests confirmed COVID-19 exposure, high inflammatory activation with myocardial involvement, and good response to IVIG. In Case \#2, the acute COVID-19 phase might date back to 2 weeks before disease onset, when the patient had fever, while Case \#1 had most likely an asymptomatic course. Case \#3, despite considered as having incomplete $\mathrm{KD}$, manifested a more typical course for KD (4). Interestingly, this patient showed lower levels of procalcitonin, C-reactive protein, D-dimers, and ferritin compared to the other two cases, even though platelet count was higher (Table I). We observed a rapid improvement of heart involvement in all patients; indeed, they all had a normal TEE at 6 weeks after hospital discharge. Over a follow-up period of 5 months, they did not have any complications. The SARS-CoV-2 exposure, either laboratory confirmed or epidemiologically based, in a patient with a classical presentation and course of KD might be ascribable to a simple epidemiological likelihood, given the current outbreak, probably like in Case \#3.
Indeed, despite this patient presented with prolonged fever and rash only, he also had other findings suggestive of KD (gallbladder hydrops, transaminitis, sterile pyuria). Furthermore, an atypical/incomplete course of KD is more common in younger patients as is coronary artery involvement. Therefore, Case 3 may be classified as a KD just temporally associated with SARSCoV-2. On the other hand, the other two cases, despite having some features similar to $\mathrm{KD}$, had a more severe disease characterized mainly by gastrointestinal symptoms and prominent myocardial impairment and, in one case, also macrophage activation syndrome (MAS) features. Furthermore, they were older (mean age of 8 years) than expected for $\mathrm{KD}$ patients for the above-mentioned features (Table II). Therefore, these peculiarities in the current epidemiological background are potentially indicative of a new nosological entity. Indeed, the term PIMS-TS has been first introduced by the Royal College of Pediatrics and Child Health (RCPCH) (5).

Right after this alert, the World Health Organization (WHO) and the Centers for Disease Control and Prevention (CDC) provided their own definitions of MIS-C (6, 7). Case \#1 and Case \#2 fit well into all the above-mentioned definitions, since both presented with persistent fever, inflammation and evidence of cardiac dysfunction with additional features (mostly gastrointestinal complaints) without an alternative microbial cause, and evidence of SARSCoV-2 exposure; on the contrary Case \#3 met the RCPCH definition only where no proven laboratory SARS-CoV-2 exposure is necessary.

In the context of the cytokine storm in adult patients with severe COVID-19, data on the efficacy of high doses of anakinra, a recombinant IL-1 receptor antagonist, are encouraging so far, even though controlled trials are currently underway (ClinicalTrials.gov NCT04318366 and NCT04324021) (15). Given these similarities, in terms of the high inflammation background, with PIMS-TS/MIS-C, anakinra might be useful for the treatment of these children as well. Indeed, preliminary data on its efficacy in 
PIMS-TS/MIS-C are promising (8, 10-12). We hypothesize that SARS-CoV-2 might act in children as a trigger, either causing a systemic inflammatory response leading to a severe KD-like phenotype eventually characterized by myocardial impairment, like in Case \#1 and \#2, or inducing the classical KD phenotype (as it might have been for Case \#3).

As for all case series, small samples make it impossible to generalize results. Furthermore, it should be highlighted that the knowledge of this condition and its clinical spectrum are not yet clear, therefore definitions are preliminary and its classification may change over time. Therefore, a careful interpretation of each piece of information is needed.

We think that bringing these cases and their differences to the attention of the rheumatology community during the COVID-19 pandemic will be beneficial in order to achieve early diagnosis and increase the awareness of this new phenomenon. Future studies are needed to better characterize these children in terms of diagnostic tools, best treatments, and long-term outcome.

\section{Conflict of interest}

The authors declare no conflict of interest.

\section{REFERENCES}

1. Sethuraman U, Kannikeswaran N, Ang J, et al. Multisystem inflammatory syndrome in children associated with novel coronavirus SARSCoV-2: Presentations to a pediatric emergency department in Michigan. Am J Emerg Med. 2020; S0735-6757(20)30931-1.

2. Verdoni L, Mazza A, Gervasoni A, et al. An outbreak of severe Kawasaki-like disease at the Italian epicentre of the SARS-CoV-2 epidemic: an observational cohort study. Lancet. 2020; 395: 1771-8

3. Riphagen S, Gomez X, Gonzalez-Martinez $\mathrm{C}$, et al. Hyperinflammatory shock in children during COVID-19 pandemic. Lancet. 2020; 395: 1607-8.

4. Mamishi S, Movahedi Z, Mohammadi M, et al. Multisystem inflammatory syndrome associated with SARS-CoV-2 infection in 45 children: a first report from Iran. Epidemiol Infect. 2020; 148: e196.

5. Royal College of Paediatrics and Child Health (2020) Guidance - Paediatric multisystem inflammatory syndrome temporally associated with COVID-19. Available from: https://www. rcpch.ac.uk/resources/guidance-paediatric-multisystem-inflammatory-syndrome-temporallyassociated-COVID-19. Accessed: 5 May 2020.

6. WHO. Multisystem inflammatory syndrome in children and adolescents with COVID-19; 2020. Available from: https://www.who.int/newsroom/commentaries/detail/multisystem-inflammatory-syndrome-in-children-and-adolescentswith-COVID-19 Accessed: 15 May 2020.

7. CDC. Multisystem Inflammatory Syndrome in Children (MIS-C) Associated with Coronavirus Disease 2019 (COVID-19); 2020. Available from: https://emergency.cdc.gov/han/2020/han 00432.asp Accessed: 14 May 2020.

8. Belhadjer Z, Méot M, Bajolle F, et al. Acute heart failure in multisystem inflammatory syndrome in children (MIS-C) in the context of global SARS-CoV-2 pandemic. Circulation. 2020; 142: 429-36.

9. Toubiana J, Poirault C, Corsia A, et al. Kawasaki-like multisystem inflammatory syndrome in children during the COVID-19 pandemic in Paris, France: prospective observational study. BMJ 2020; 369: m2094.

10. Pouletty M, Borocco C, Ouldali N, et al. Paediatric multisystem inflammatory syndrome temporally associated with SARS-CoV-2 mimicking Kawasaki disease (Kawa-COVID-19): a multicentre cohort. Ann Rheum Dis. 2020; 79: 999-1006.

11. Whittaker E, Bamford A, Kenny J, et al. PIMS-TS Study Group and EUCLIDS and PERFORM Consortia. Clinical Characteristics of 58 Children With a Pediatric Inflammatory Multisystem Syndrome Temporally Associated With SARS-CoV-2. JAMA. 2020; 324: 259-69.

12. Feldstein LR, Rose EB, Horwitz SM, et al. Multisystem inflammatory syndrome in U.S. children and adolescents. N Engl J Med. 2020; 383: 334-46.

13. Dufort EM, Koumans EH, Chow EJ, et al. New York State and Centers for Disease Control and Prevention Multisystem Inflammatory Syndrome in Children Investigation Team. Multisystem inflammatory syndrome in children in New York State. N Engl J Med. 2020; 383: 347-58.

14. Ramcharan T, Nolan O, Lai CY, et al. Paediatric inflammatory multisystem syndrome: temporally associated with SARS-CoV-2 (PIMS-TS): cardiac features, management and short-term outcomes at a UK Tertiary Paediatric Hospital. Pediatr Cardiol. 2020; 41: 1391-401.

15. Cavalli G, De Luca G, Campochiaro C, et al. Interleukin-1 blockade with high-dose anakinra in patients with COVID-19, acute respiratory distress syndrome, and hyperinflammation: a retrospective cohort study. Lancet Rheumatol. 2020; 2: e325-31. 